\title{
KAJIAN KUAT DESAK DAN MODULUS ELASTISITAS PADA BETON MUTU TINGGI DENGAN BAHAN TAMBAH ABU SEKAM PADI MENGGUNAKAN ANALISIS MIKROSTRUKTUR
}

\author{
Wibowo'), Endah Safitri'2), Dicky Apriawang3) \\ 1) 2) Pengajar Program Studi Teknik Sipil, Fakultas Teknik, Universitas Sebelas Maret Surakarta \\ 3) Mahasiswa Program Studi Teknik Sipil, Fakultas Teknik, Universitas Sebelas Maret
}

\begin{abstract}
Concrete is the most widely used building material. One of the innovations is high strength concrete which is commonly used in high-rise building projects. This research innovates by using rice husk ash as a variety of ingredients added to a portion of cement. The reason for using rice husk ash is due to the high $\mathrm{SiO}_{2}$ content which can increase the strength of the pressure and modulus of elasticity of the concrete. This study aims to examine how strong the pressure and the modulus of elasticity of high quality concrete with ingredients added to rice husk ash with a level of $10 \%$ using microstructure analysis at the ages of 7, 14, 21, and 28 days. The test object used in this research was cylindrical concrete with a diameter of $7.5 \mathrm{~cm}$ and a height of $15 \mathrm{~cm}$. Tests carried out in this study include material testing, slump test, compressive strength test and elastic modulus using Universal Testing Machine (UTM), and microstructure test using Surface Area Analyzer (SAA). The results showed an increase in the strong value of the pressure of concrete with material added by rice husk ash to normal concrete on the 7th, 14th, 21st, and 28th days of -8.04\% respectively; -5.96\%; $0.34 \% ; 8.45 \%$. Meanwhile for the percentage increase in the modulus of elasticity on day 714,21 and 28 days is $3.01 \% ;-2.23 \% ; 0.13 \% ; 3.14 \%$. The addition of rice husk ash also made pore volume values increase at 7, 14, 21, and 28 days of sample at $6.90 \% ; 3.57 \% ;-12.50 \% ;-27.27 \%$.
\end{abstract}

Keywords: compressive strength, concrete microstructure, elastic modulus, fresh concrete testing, high strength concrete, rice husk. ash.

\begin{abstract}
Abstrak
Beton merupakan material bangunan yang paling banyak digunakan. Salah satu inovasinya ialah beton mutu tinggi yang biasa digunakan pada proyek gedung-gedung tinggi. Penelitian ini melakukan inovasi dengan menggunakan abu sekam padi sebagai variasi bahan tambah pengganti sebagian semen. Alasan penggunaan abu sekam padi adalah dikarenakan adanya kandungan $\mathrm{SiO}_{2}$ yang tinggi yang dapat meningkatkan nilai kuat desak serta modulus elastisitas beton. Penelitian ini bertujuan untuk mengkaji bagaimana kuat desak serta modulus elastisitas beton mutu tinggi dengan bahan tambah abu sekam padi dengan kadar 10\% menggunakan analisis mikrostruktur pada umur 7, 14, 21, dan 28 hari. Benda uji yang digunakan pada penelitian ini berupa beton silinder dengan diameter $7,5 \mathrm{~cm}$ dan tinggi $15 \mathrm{~cm}$. Pengujian yang dilakukan pada penelitian ini meliputi uji material, uji slump, uji kuat desak dan modulus elastisitas menggunakan Universal Testing Machine (UTM), serta uji mikrostruktur menggunakan alat Surface Area Analyser (SAA). Hasil penelitian menunjukkan adanya peningkatan nilai kuat desak beton dengan bahan tambah abu sekam padi terhadap beton normal pada hari ke- 7, 14, 21, dan 28 hari masing-masing sebesar $-8,04 \% ;-5,96 \% ; 0,34 \% ; 8,45 \%$. Sementara itu untuk persentase peningkatan nilai modulus elastisitas pada hari ke- 7 14, 21, dan 28 hari adalah sebesar -3,01\%;-2,23\%; 0,13\%; 3,14\%. Penambahan abu sekam padi juga membuat nilai volume pori mengalami peningkatan pada umur sampel ke- 7, 14, 21, dan 28 hari masing-masing sebesar $6,90 \% ; 3,57 \% ;-12,50 \% ;-27,27 \%$.
\end{abstract}

Kata Kunci : abu sekam padi, beton mutu tinggi, kuat desak, modulus elastisitas, mikrostruktur beton, pengujian beton segar.

\section{PENDAHULUAN}

Perkembangan dunia konstruksi sekarang ini terjadi begitu pesat. Hal ini dapat terlihat dari maraknya pembangunan infrastruktur, seperti gedung, jalan, jembatan, ataupun bangunan air. Meningkatnya pembangunan konstruksi yang ada tentu perlu diimbangi dengan ketersediaan material bangunan. Material bangunan yang sering digunakan dalam dunia konstruksi ialah beton. Mengacu pada semakin meningkatnya kebutuhan akan beton, maka perlu adanya inovasi-inovasi untuk menciptakan beton dengan kualitas yang baik, seperti beton mutu tinggi.

Namun disisi lain inovasi beton mutu tinggi ini nantinya dalam komposisi campurannya akan memerlukan bahan pengikat berupa semen yang lebih banyak. Hal ini tentu akan menimbulkan masalah baru karena industri semen 
yang berlebihan akan menyebabkan dampak buruk bagi lingkungan Oleh karena itu perlu adanya alternatif bahan tambah untuk mengurangi penggunaan semen.

Dalam penelitian ini bahan tambah yang digunakan untuk mengurangi penggunaan semen adalah abu sekam padi. Alasan penggunaan abu sekam padi adalah dikarenakan adanya kandungan $\mathrm{SiO}_{2}$ yang tinggi yang dapat meningkatkan nilai kuat desak dan modulus elastisitas beton. Selain itu dalam penelitian ini juga menggunakan bahan tambah kimia superplasticizer untuk meningkatkan kelecakan beton.

\section{TINJAUAN PUSTAKA DAN LANDASAN TEORI}

Beton merupakan fungsi dari bahan penyusunnya yang terdiri dari bahan semen portland, agregat kasar, agregat halus, dan air dengan atau tanpa menggunakan bahan tambah baik berupa admixture atau additive. Sampai dengan saat ini beton masih menjadi material utama yang digunakan dalam dunia konstruksi. Hal ini disebabkan oleh tingginya kuat desak yang dimiliki beton, kemudahan dalam mencari material penyusun beton, serta kemudahan dalam pengerjaanya (Mulyono, 2003).

Beton memiliki banyak sekali inovasi, salah satunya adalah beton mutu tinggi. Beton mutu tinggi banyak digunakan untuk pekerjaan-pekerjaan khusus, seperti pada proyek gedung-gedung tinggi. Menurut SNI 03-64682000 beton mutu tinggi adalah beton yang memiliki nilai kuat desak yang lebih besar sama dengan 41,4 Mpa.

Menurut Hardjasaputra (2008), beton dengan kuat desak tinggi dapat dibuat dengan penambahan bahan kimia yaitu superplasticizer. Penambahan superplasticizer pada beton bertujuan untuk mendispersi partikel semen dengan seragam. Selain itu penggunaan superplasticizer juga dapat mengurangi kebutuhan air, sehingga dapat mengurangi porositas beton dan meningkatkan kekuatan beton.

Berdasarkan ASTM C-618, pozzolan adalah bahan yang mengandung silika atau silika alumina yang belum tentu memiliki sifat semen, namun jika dalam bentuk butiran yang halus dan dalam keadaan yang lembab bahan pozzolan ini dapat bereaksi secara kimia dengan $\mathrm{Ca}(\mathrm{OH})_{2}$ pada suhu biasa untuk membentuk senyawa bersifat semen. Material pozzolan yang bersifat alami salah satunya adalah abu sekam padi (rice busk ash).

Menurut Mulyono (2005), faktor-faktor yang mempengaruhi kekuatan beton adalah agregat kasar, pasta serta Interface Transition Zone (ITZ). Selanjutnya, ITZ sendiri merupakan suatu zona peralihan sebesar 30 mili mikron antara pasta dengan agregat.

Kuat desak beton adalah kemampuan beton dalam menahan gaya tekan. Nilai kuat desak beton dapat dihitung dengan persamaan [1].

$f^{\prime} c=\frac{P}{A}$

dengan:

$f^{\prime} \mathrm{C}=$ Kuat desak beton $(\mathrm{MPa})$

$\mathrm{P} \quad=$ Gaya desak $(\mathrm{N})$

A = Luas penampang benda uji $\left(\mathrm{mm}^{2}\right)$

Modulus elastisitas adalah hubungan antara tegangan dan regangan yang harus diketahui guna menurunkan persamaan analisis dan desain pada struktur beton. Untuk menghitung modulus elastisitas ada beberapa persamaan yang digunakan, diantaranya:

1. ASTM C469

$$
E c=\frac{0,4 f^{\prime} c-\sigma_{1}}{\varepsilon_{0,4 f^{\prime} c}-\varepsilon_{1}}
$$

2. Eurocode 2-1992

$$
E c=\frac{0,4 f^{\prime} c}{\varepsilon_{0,4 f^{\prime} c}}
$$

3. ACI Committee 363-10

$$
E c=3320 \sqrt{f^{\prime} c}+6900
$$

4. SNI 2847-2013

$$
E c=0,043 w_{c}{ }^{1,5} \sqrt{f^{\prime} c} \text { untuk } 1500<\mathrm{w}_{c}<2500 \mathrm{~kg} / \mathrm{m}^{3}
$$




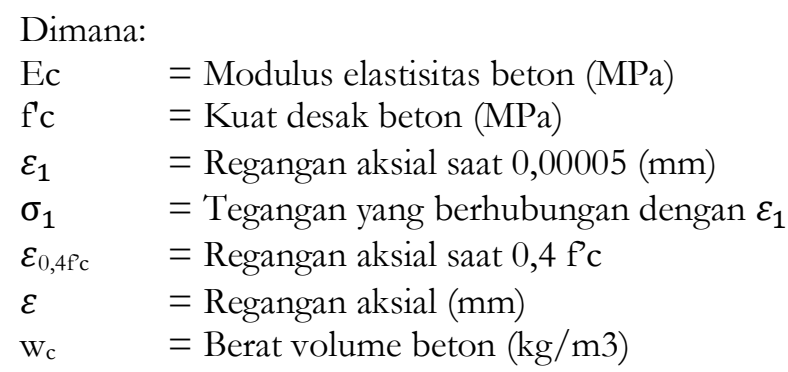

Mikrostruktur beton dapat dianalisis melalui alat Surface Area Analyser (SAA) dimana nanti hasil pengujian akan diperoleh nilai luas permukaan dan nilai volume pori, dimana nilai volume pori memiliki kaitan dengan tingkat porositas beton sehingga mempengaruhi kekuatan beton.

\section{METODE}

Metode pengerjaan yang dilakukan pada penelitian ini adalah berupa metode eksperimental yang dilakukan di Laboratorium Bahan dan Struktur Program Studi Teknik Sipil serta Laboratorium Fakultas MIPA Terpadu Universitas Sebelas Maret Surakarta. Pengujian yang dilakukan berupa uji kuat desak, modulus elastisitas, dan mikrostruktur pada sampel beton yang berumur ke-7, 14, 21, dan 28 hari. Benda uji yang digunakan beton silinder dengan diameter $7,5 \mathrm{~cm}$ dan tinggi $15 \mathrm{~cm}$ sejumlah 24 buah. Keterangan mengenai benda uji dapat dilihat pada Tabel 1.

Tabel 1. Kode dan Jumlah Benda Uji

\begin{tabular}{|c|c|c|c|c|c|}
\hline No & $\begin{array}{l}\text { Umur } \\
\text { Beton } \\
\text { (hari) }\end{array}$ & $\begin{array}{c}\text { Kode Benda Uji dengan } \\
\text { Abu Sekam Padi }\end{array}$ & $\begin{array}{l}\text { Jumlah } \\
\text { Benda Uji }\end{array}$ & $\begin{array}{c}\text { Kode Benda Uji } \\
\text { tanpa } \\
\text { Abu Sekam Padi }\end{array}$ & $\begin{array}{c}\text { Jumlah } \\
\text { Benda } \\
\text { Uji }\end{array}$ \\
\hline \multirow{3}{*}{1} & \multirow{3}{*}{7} & $\mathrm{~B}_{\mathrm{HSC}} \mathrm{ASP} 7-\mathrm{A}$ & \multirow{3}{*}{3} & $\mathrm{~B}_{\mathrm{HSC}} \mathrm{N} 7-\mathrm{A}$ & \multirow{3}{*}{3} \\
\hline & & $\mathrm{B}_{\mathrm{HSC}}$ ASP $7-\mathrm{B}$ & & $\mathrm{B}_{\mathrm{HSC}} \mathrm{N} 7-\mathrm{B}$ & \\
\hline & & $\mathrm{B}_{\mathrm{HSC}}$ ASP $7-\mathrm{C}$ & & $\mathrm{B}_{\mathrm{HSC}} \mathrm{N} 7-\mathrm{C}$ & \\
\hline \multirow{3}{*}{2} & \multirow{3}{*}{14} & $\mathrm{~B}_{\mathrm{HSC}}$ ASP $14-\mathrm{A}$ & \multirow{3}{*}{3} & $\mathrm{~B}_{\mathrm{HSC}} \mathrm{N} 14-\mathrm{A}$ & \multirow{3}{*}{3} \\
\hline & & $\mathrm{B}_{\mathrm{HSC}}$ ASP $14-\mathrm{B}$ & & $\mathrm{B}_{\mathrm{HSC}} \mathrm{N} 14-\mathrm{B}$ & \\
\hline & & $\mathrm{B}_{\text {HSC }}$ ASP $14-\mathrm{C}$ & & $\mathrm{B}_{\text {HSC }} \mathrm{N} 14-\mathrm{C}$ & \\
\hline \multirow{3}{*}{3} & \multirow{3}{*}{21} & $\mathrm{~B}_{\text {HSC }}$ ASP $21-\mathrm{A}$ & \multirow{3}{*}{3} & $\mathrm{~B}_{\text {HSC }} \mathrm{N} 21-\mathrm{A}$ & \multirow{3}{*}{3} \\
\hline & & $\mathrm{B}_{\mathrm{HSC}}$ ASP $21-\mathrm{B}$ & & $\mathrm{B}_{\mathrm{HSC}} \mathrm{N} 21-\mathrm{B}$ & \\
\hline & & $\mathrm{B}_{\mathrm{HSC}}$ ASP $21-\mathrm{C}$ & & $\mathrm{B}_{\mathrm{HSC}} \mathrm{N} 21-\mathrm{C}$ & \\
\hline \multirow{3}{*}{4} & \multirow{3}{*}{28} & $\mathrm{~B}_{\mathrm{HSC}}$ ASP $28-\mathrm{A}$ & & $\mathrm{B}_{\mathrm{HSC}} \mathrm{N} 28-\mathrm{A}$ & \multirow{3}{*}{3} \\
\hline & & $\mathrm{B}_{\mathrm{HSC}}$ ASP $28-\mathrm{B}$ & 3 & $\mathrm{~B}_{\mathrm{HSC}} \mathrm{N} 28-\mathrm{B}$ & \\
\hline & & $\mathrm{B}_{\mathrm{HSC}}$ ASP $28-\mathrm{C}$ & & $\mathrm{B}_{\text {HSC }} \mathrm{N} 28-\mathrm{C}$ & \\
\hline \multicolumn{3}{|c|}{ Total Benda Uji ASP } & 12 & Total Benda Uji N & 12 \\
\hline \multicolumn{3}{|r|}{ Jumlah Total Benda Uji } & & & \\
\hline
\end{tabular}

Pengujian beton segar dilakukan melalui uji slump beton. Kemudai setelah beton mengeras baru dilakukan uji kuat desak maupun modulus elastisitas yang dilakukan menggunakan alat UTM (Universal Testing Machine). Sementara itu untuk pengujian mikrostruktur beton dilakukan dengan alat SAA (Surface Area Analyser). Masing-masing pengujian pada beton keras dilakukan pada umur beton ke- 7, 14, 21, dan 28 hari.

\section{HASIL DAN PEMBAHASAN}

Rancang Campur (Mix Design)

Komposisi material penyusun beton yang digunakan tiap $1 \mathrm{~m}^{3}$ beton dapat dilihat pada Tabel 2 .

Tabel 2. Mix Design $\mathrm{B}_{\mathrm{HSC}} \mathrm{N}$ dan $\mathrm{B}_{\mathrm{HSC}}$ ASP $10 \%$ per $1 \mathrm{~m}^{3}$

\begin{tabular}{ccccccc}
\hline Kode & $\begin{array}{c}\text { Ag. Kasar } \\
\left.\mathbf{( K g} / \mathbf{m}^{3}\right)\end{array}$ & $\begin{array}{c}\text { Ag. } \\
\mathbf{H a l u s} \\
\left(\mathbf{K g} / \mathbf{m}^{3}\right)\end{array}$ & $\begin{array}{c}\text { Semen } \\
\left(\mathbf{K g} / \mathbf{m}^{3}\right)\end{array}$ & $\begin{array}{c}\text { Abu } \\
\text { Sekam } \\
\mathbf{P a d i} \\
\left.\mathbf{( K g} / \mathbf{m}^{3}\right)\end{array}$ & $\begin{array}{c}\text { Air } \\
\left(\mathbf{l t} / \mathbf{m}^{3}\right)\end{array}$ & $\begin{array}{c}\text { Admixtures } \\
\left(\mathbf{l t} / \mathbf{m}^{3}\right)\end{array}$ \\
\hline B HSC $N^{B_{\text {HSC ASP }}}$ & 991,98 & 780,67 & 550 & 0 & 123,75 & 7,15 \\
$10 \%$ & 956,84 & 753,01 & 495 & 55 & 123,75 & 7,15 \\
\hline
\end{tabular}




\section{Pengujian Slump}

Hasil pengujian slump pada beton $\mathrm{B}_{\mathrm{HSC}} \mathrm{N}$ maupun $\mathrm{B}_{\mathrm{HSC}}$ ASP disajikan dalam bentuk diagram yang dapat dilihat pada Gambar 1.

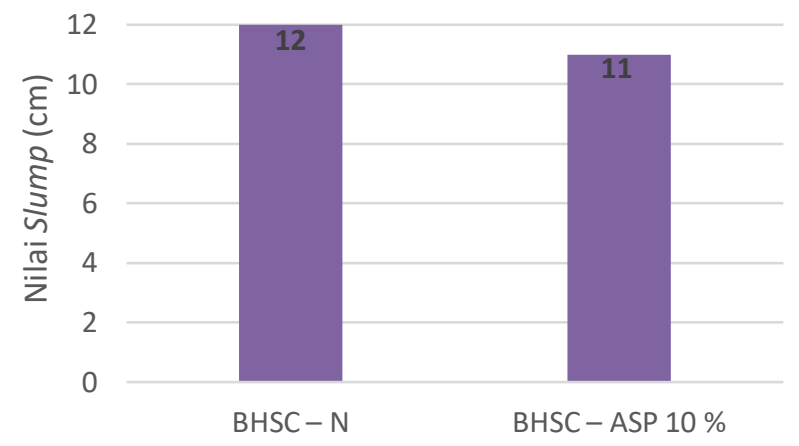

Gambar 1. Diagram Hasil Pengujian Slump

Berdasarkan Gambar 1 dapat dilihat bahwa tingkat kelecakan pada beton dengan bahan tambah abu sekam padi lebih rendah dibanding beton normal disebabkan oleh luas permukaan abu sekam padi yang lebih besar dari semen, sehingga beton dengan bahan tambah abu sekam padi lebih banyak menyerap air. Namun beton $\mathrm{B}_{\text {HSC }}$ ASP maupun $\mathrm{B}_{\mathrm{HSC}} \mathrm{N}$ masing-masing memenuhi syarat nilai slump rencana yaitu antara 7,5 $-15 \mathrm{~cm}$ (Tjokrodimulyo, 1992).

\section{Kuat Desak}

Rekpitulasi hasil pengujian kuat desak pada beton $\mathrm{B}_{\mathrm{HSC}} \mathrm{N}$ maupun $\mathrm{B}_{\mathrm{HSC}}$ ASP pada umur beton ke- 7, 14, 21, dan 28 hari dapat dilihat pada Tabel 3.

Tabel 3. Pengaruh Abu Sekam Padi terhadap Nilai Kuat Desak Beton

\begin{tabular}{|c|c|c|c|}
\hline Umur & Beton & $\begin{array}{c}\mathbf{f}^{\prime c} \\
(\mathbf{M P a})\end{array}$ & $\begin{array}{c}\text { Persentase Kenaikan f'c } \\
\mathbf{B}_{\mathrm{HSC}} \text { ASP terhadap } \mathbf{B}_{\mathrm{HSC}} \mathbf{N} \\
(\%)\end{array}$ \\
\hline \multirow{2}{*}{7 Hari } & $\mathrm{B}_{\mathrm{HSC}} \mathrm{N} 7$ & 31,75 & \multirow{2}{*}{$-8,04$} \\
\hline & $\mathrm{B}_{\mathrm{HSC}}$ ASP7 & 29,20 & \\
\hline \multirow{2}{*}{14 Hari } & $\mathrm{B}_{\mathrm{HSC}} \mathrm{N} 14$ & 34,64 & \multirow{2}{*}{$-5,96$} \\
\hline & $\mathrm{B}_{\mathrm{HSC}}$ ASP14 & 32,58 & \\
\hline \multirow{2}{*}{21 Hari } & $\mathrm{B}_{\mathrm{HSC}} \mathrm{N} 21$ & 39,74 & \multirow{2}{*}{0.34} \\
\hline & $\mathrm{B}_{\mathrm{HSC}}$ ASP21 & 39,87 & \\
\hline \multirow{2}{*}{28 Hari } & $\mathrm{B}_{\mathrm{HSC}} \mathrm{N} 28$ & 42,59 & \multirow{2}{*}{8,45} \\
\hline & B $_{\text {HSC }}$ ASP28 & 46,19 & \\
\hline
\end{tabular}

Berdasarkan Tabel 3 dapat dilihat bahwa nilai kuat desak beton dengan bahan tambah abu sekam padi memiliki nilai f'c rata-rata yang lebih rendah dibanding beton normal diumur ke- 7 dan 14 hari. Hal ini terjadi karena senyawa $\mathrm{C}_{3} \mathrm{~S}$ dan $\mathrm{C}_{3} \mathrm{~A}$ yang terkandung didalam semen yang berperan dalam meningkatkan kekuatan awal beton pada saat reaksi hidrasi terganggu karena adanya campuran butiran abu sekam padi. Reaksi hidrasi senyawa $\mathrm{C}_{3} \mathrm{~S}$ dan $\mathrm{C}_{3} \mathrm{~A}$ yang berlangsung lebih lama akan mengakibatkan mengerasnya beton akan lebih lama (Robbani, 2018).

Namun saat sudah mencapai umur 21 hari, dapat dilihat bahwa nilai fe rata-rata beton dengan bahan tambah abu sekam padi lebih besar dibanding beton normal, yaitu meningkat sebesar $0,34 \%$. Selanjutnya saat memasuki hari ke-28 beton dengan bahan tambah abu sekam padi memiliki nilai $\mathrm{fc}$ rata-rata yang lebih tinggi dibanding beton normal, yaitu meningkat sebesar $8,45 \%$. Hal ini disebabkan ukuran butiran abu sekam padi yang sangat kecil, sehingga abu sekam padi dapat berperan sebagai filler yang dapat mengisi rongga diantara agregat dan pasta semen. Hal ini menyebabkan rongga-rongga diantara agregat dan pasta semen atau daerah ITZ menjadi berkurang. Semakin kecilnya resiko microcracking di ITZ menyebabkan meningkatnya kepadatan beton saat menerima beban, sehingga kekuatan beton menjadi bertambah. 
Selain itu, dilihat dari sifat kimia abu sekam padi yang merupakan bahan pozzoalan alami sehingga mengandung senyawa $\mathrm{SiO}_{2}$ sebesar 84,91\% (dari hasil pengujian XRF). Senyawa $\mathrm{SiO}_{2}$ ini nantinya yang akan bereaksi dengan senyawa $\mathrm{Ca}(\mathrm{OH}) 2$ yang merupakan hasil reaksi hidrasi semen. Reaksi keduanya akan membentuk senyawa $\mathrm{CSH}$ sekunder sama seperti yang dihasilkan pada proses hidrasi semen CSH primer. Untuk lebih jelasnya dapat dilihat di bawah ini:

Reaksi Hidrasi Semen:

$$
\begin{aligned}
& \mathrm{C}_{3} \mathrm{~S}, \mathrm{C}_{2} \mathrm{~S} \quad+\mathrm{H}_{2} \mathrm{O} \longrightarrow \quad \text { CSHprimer } \quad+\mathrm{Ca}(\mathrm{OH})_{2} \\
& \text { Senyawa Semen }+ \text { Air } \longrightarrow \text { Kalsium Silikat Hidrat }+ \text { Kalsium Hidroksida }
\end{aligned}
$$

Reaksi Pozzolanik:

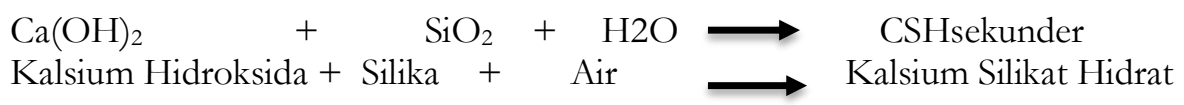

Senyawa Kalsium Silikat Hidrat ini sangat penting karena senyawa ini berperan mengikat agregat, sehingga mampu mengurangi rongga pada daerah ITZ. Hal inilah yang membuat beton dengan bahan tambah abu sekam padi memiliki kuat desak yang lebih tinggi.

Namun jika dilihat dari sisi umur beton, berdasarkan Tabel 3 dapat dilihat bahwa semakin bertambahnya umur beton maka nilai kuat desaknya juga semakin meningkat baik beton $\mathrm{B}_{\mathrm{HSC}} \mathrm{N}$ maupun $\mathrm{B}_{\mathrm{HSC}}$ ASP. Hubungan nilai kuat desak dengan umur beton dapat dilihat pada Gambar 2.

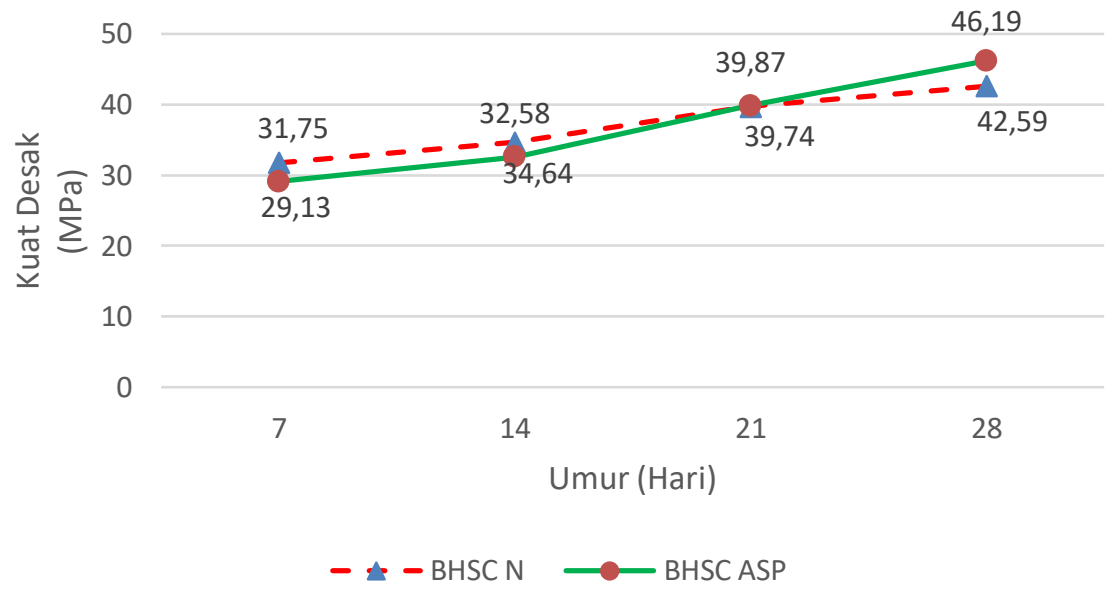

Gambar 2. Hubungan Kuat Desak dengan Umur Beton

\section{Modulus Elastisitas}

Nilai modulus elastisitas dapat dihitung berdasar pada gambar grafik hubungan tegangan-regangan dengan menggunakan Persamaan 2 (ASTM C469) dan Persamaan 3 (Eurocode 2-1992) berdasarkan hasil plotting pada grafik tersebut. Selanjutnya nilai modulus elastisitas tersebut dibandingkan dengan nilai modulus elastisitas teoritis dari Persamaan 4 (ACI Committee 363-10) dan Persamaan 5 (SNI 2847-2013).

Rekapitulasi hasil perhitungan modulus elastisitas percobaan dan teoritis untuk beton $\mathrm{B}_{\mathrm{HSC}} \mathrm{N}$ maupun $\mathrm{B}_{\mathrm{HSC}}$ ASP pada umur ke- 7, 14, 21, dan 28 hari dapat dilihat pada Tabel 4.

Tabel 4. Rekapitulasi Modulus Elastisitas

Ec Percobaan (MPa) $\quad$ Ec Perhitungan (MPa)

\begin{tabular}{cccccc} 
Umur & Beton & $\begin{array}{c}\text { Eurocode } \\
\mathbf{2 - 1 9 9 2}\end{array}$ & $\begin{array}{c}\text { ASTM } \\
\text { C469 }\end{array}$ & $\begin{array}{c}\text { ACI } \\
\text { Committee } \\
\mathbf{3 6 3 - 1 0}\end{array}$ & $\begin{array}{c}\text { SNI } \\
\mathbf{2 8 4 7 - 2 0 1 3}\end{array}$ \\
\hline 7 & $\mathrm{~B}_{\mathrm{HSC}} \mathrm{N} 7$ & 24760,17 & 25436,67 & 25606,99 & 29806,81 \\
\hline
\end{tabular}




\begin{tabular}{|c|c|c|c|c|c|}
\hline & $\mathrm{B}_{\mathrm{HSC}}$ ASP7 & 23829,16 & 24250,00 & 24836,73 & 27644,93 \\
\hline \multirow{2}{*}{14} & $\mathrm{~B}_{\mathrm{HSC}} \mathrm{N} 14$ & 27944,10 & 28173,00 & 26439,81 & 31133,78 \\
\hline & $\mathrm{B}_{\mathrm{HSC}} \mathrm{ASP} 14$ & 25635,46 & 26447,33 & 25849,61 & 29050,99 \\
\hline \multirow{2}{*}{21} & $\mathrm{~B}_{\mathrm{HSC}} \mathrm{N} 21$ & 31794,25 & 29576,67 & 27828,15 & 33345,88 \\
\hline & $\mathrm{B}_{\mathrm{HSC}} \mathrm{ASP} 21$ & 29578,52 & 30608,00 & 27863,98 & 32139,14 \\
\hline \multirow{2}{*}{28} & $\mathrm{~B}_{\mathrm{HSC}} \mathrm{N} 28$ & 31968,00 & 31497,00 & 28567,25 & 34523,54 \\
\hline & $\mathrm{B}_{\mathrm{HSC}}$ ASP28 & 33595,15 & 33274,00 & 29463,94 & 34655,03 \\
\hline
\end{tabular}

Berdasarkan Tabel 4 dapat dilihat bahwa nilai modulus elastisitas percobaan dan perhitungan pada beton $\mathrm{B}_{\mathrm{HSC}} \mathrm{N}$ maupun $\mathrm{B}_{\mathrm{HSC}}$ ASP nilainya semakin meningkat seiring dengan bertambahnya umur beton tersebut. Peningkatan nilai modulus elastis beton $\mathrm{B}_{\mathrm{HSC}}$ ASP dibanding $\mathrm{B}_{\mathrm{HSC}} \mathrm{N}$ paling signifikan terjadi pada saat umur beton ke- 28 hari. Peningkatan ini terjadi disebabkan oleh adanya reaksi pozolanik yang dapat meningkatkan produksi CSH yang berperan sebagagai pengikat serta pengaruh peran abu sekam padi yang dapat berfungsi sebagai filler yang dapat mengisi rongga-rongga diantara pasta dan agregat (ITZ). Hal inilah yang membuat porositas beton menjadi berkurang, sehingga beton menjadi lebih tahan terhadap gaya desak serta nilai modulus elastisitasnya juga semakin meningkat. Berikut disajikan grafik modulus elastisitas pada beton umur 28 hari pada Gambar 3.

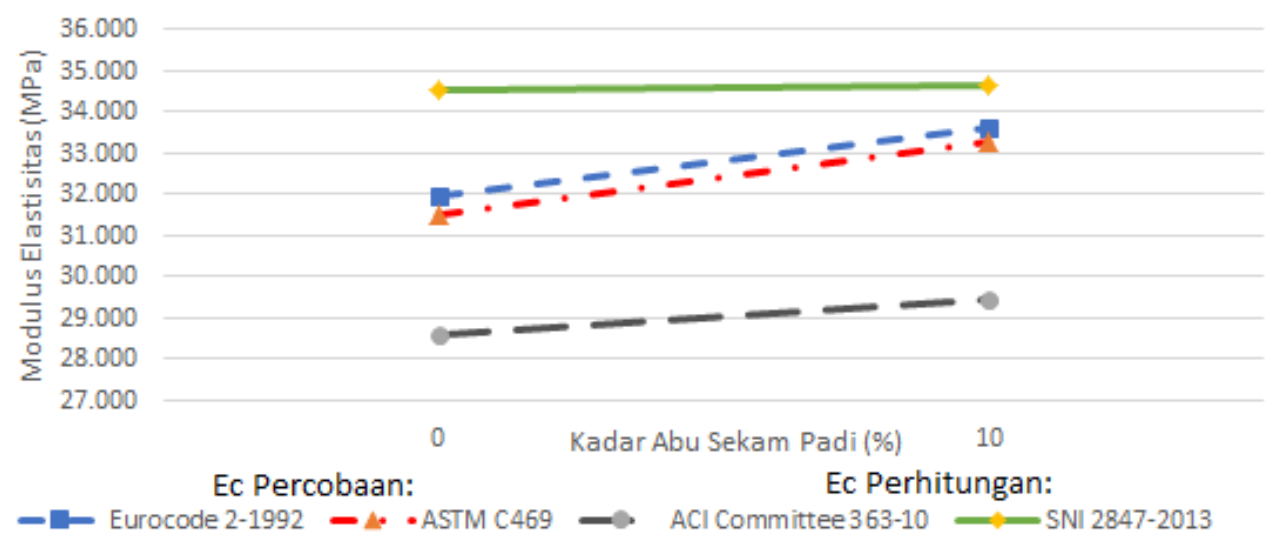

Gambar 3. Grafik Modulus Elastisitas Percobaan dan Perhitungan Umur 28 Hari

\section{Mikrostruktur Beton}

Pengujian SAA (Surface Area Analysis) dilakukan pada sampel beton berumur 7, 14, 21, dan 28 hari dengan menggunakan alat Surface Area Analyser. Sampel yang digunakan pada pengujian ini berupa pasta dari pecahan sampel beton yang sebelumnya sudah dilakukan uji kuat desak dan telah ditumbuk halus serta lolos ayakan no 50 $(0,3 \mathrm{~mm})$.

Data hasil pengujian SAA dari sampel beton $\mathrm{B}_{\mathrm{HSC}} \mathrm{N}$ dan $\mathrm{B}_{\mathrm{HSC}}$ ASP pada umur ke- 7, 14, 21, 28 hari dapat dilihat pada Tabel 5.

Tabel 5. Hasil Pengujian SAA

\begin{tabular}{|c|c|c|c|c|}
\hline Umur & Beton & Radius Pori (A) & Volume Pori (cc/g) & Luas Permukaan $\left(\mathrm{m}^{2} / \mathrm{g}\right)$ \\
\hline \multirow{2}{*}{7 Hari } & $\mathrm{B}_{\mathrm{HSC}} \mathrm{N} 7$ & 18,23 & 0,029 & 22,11 \\
\hline & $\mathrm{B}_{\mathrm{HSC}}$ ASP7 & 18,56 & 0,031 & 23,21 \\
\hline \multirow{2}{*}{14 Hari } & $\mathrm{B}_{\mathrm{HSC}} \mathrm{N14}$ & 18,22 & 0,028 & 20,45 \\
\hline & $\mathrm{B}_{\mathrm{HSC}} \mathrm{ASP} 14$ & 18,18 & 0,029 & 21,18 \\
\hline \multirow{2}{*}{21 Hari } & $\mathrm{B}_{\text {HSC }} \mathrm{N} 21$ & 18,17 & 0,024 & 15,71 \\
\hline & $\mathrm{B}_{\mathrm{HSC}}$ ASP21 & 18,05 & 0,021 & 12,96 \\
\hline 28 Hari & $\mathrm{B}_{\mathrm{HSC}} \mathrm{N} 28$ & 18,13 & 0,022 & 11,98 \\
\hline
\end{tabular}


Berdasarkan Tabel 5 dapat dilihat hubungan antara luas permukaan dengan volume pori berbanding lurus, yaitu semakin kecil volume pori maka luas pernukaan juga semakin kecil. Selain itu hubungan antara volume pori dengan umur beton juga berbanding lurus dimana semakin bertambahnya umur beton $\mathrm{B}_{\mathrm{HSC}} \mathrm{N}$ dan $\mathrm{B}_{\mathrm{HSC}}$ ASP, maka volume porinya juga semakin kecil. Perbandingan volume pori pasta antara beton $\mathrm{B}_{\mathrm{HSC}} \mathrm{N}$ dan $\mathrm{B}_{\mathrm{HSC}}$ ASP dapat dilihat pada Gambar 4.

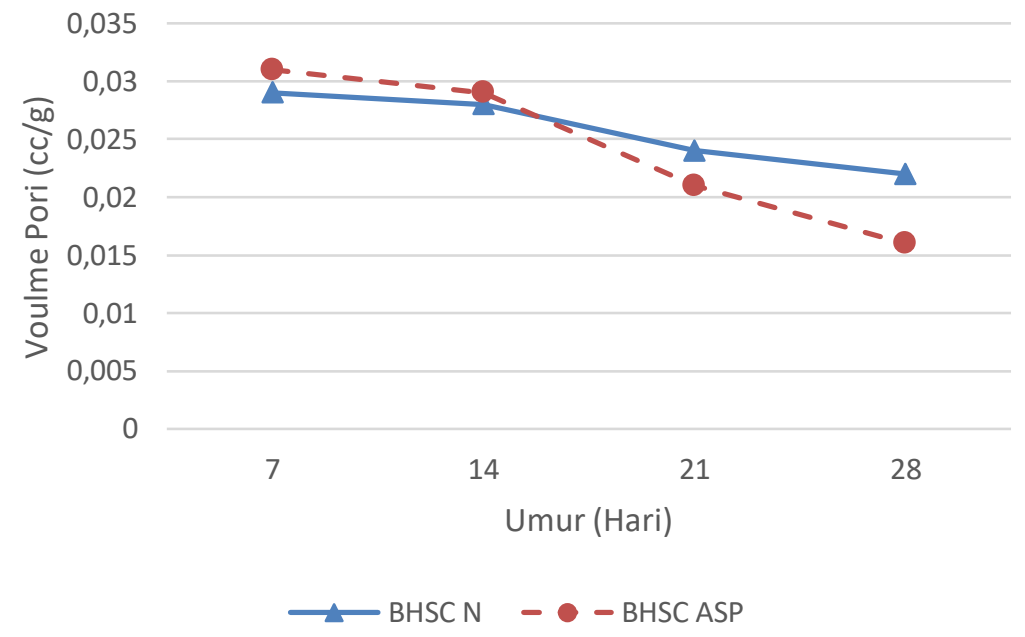

Gambar 4. Perbandingan Volume Pori antara Pasta Beton $\mathrm{B}_{\mathrm{HSC}} \mathrm{N}$ dan $\mathrm{B}_{\mathrm{HSC}}$ ASP

Berdasarkan Gambar 4. didapatkan bahwa tingkat porositas pasta beton $B_{H S C}$ ASP lebih besar dibandingkan dengan beton $\mathrm{B}_{\mathrm{HSC}} \mathrm{N}$ pada sampel beton dengan umur 7, 14 hari. Hal ini terjadi karena senyawa $\mathrm{C}_{3} \mathrm{~S}$ dan $\mathrm{C}_{3} \mathrm{~A}$ yang terkandung didalam semen yang berperan sebagai bahan pengikat agregat pada saat hidrasi terganggu karena adanya campuran butiran abu sekam padi. Namun setelah memasuki hari ke- 21 dan 28 , beton BHSC ASP memiliki tingkat porositas yang lebih kecil dibanding beton $\mathrm{B}_{\mathrm{HSC}} \mathrm{N}$. Hal ini disebabkan peran abu sekam padi yang dapat berfungsi sebagai filler sehingga dapat mengisi rongga yang ada dalam pasta semen. Selain itu menurut Zhank, dkk (1996) dalam penelitiannya mengatakan bahwa pasta semen dengan campuran abu sekam padi memiliki kandungan $\mathrm{Ca}(\mathrm{OH}) 2$ yang rendah. Kadar $\mathrm{Ca}(\mathrm{OH}) 2$ yang rendah ini membuat daerah pertemuan agregat dengan pasta semen semakin tipis atau dengan kata lain porositasnya semakin kecil. Hubungan volume pori terhadap nilai kuat desak dan modulus elastisitas beton dapat dilihat pada Gambar 5 dan Gambar 6.

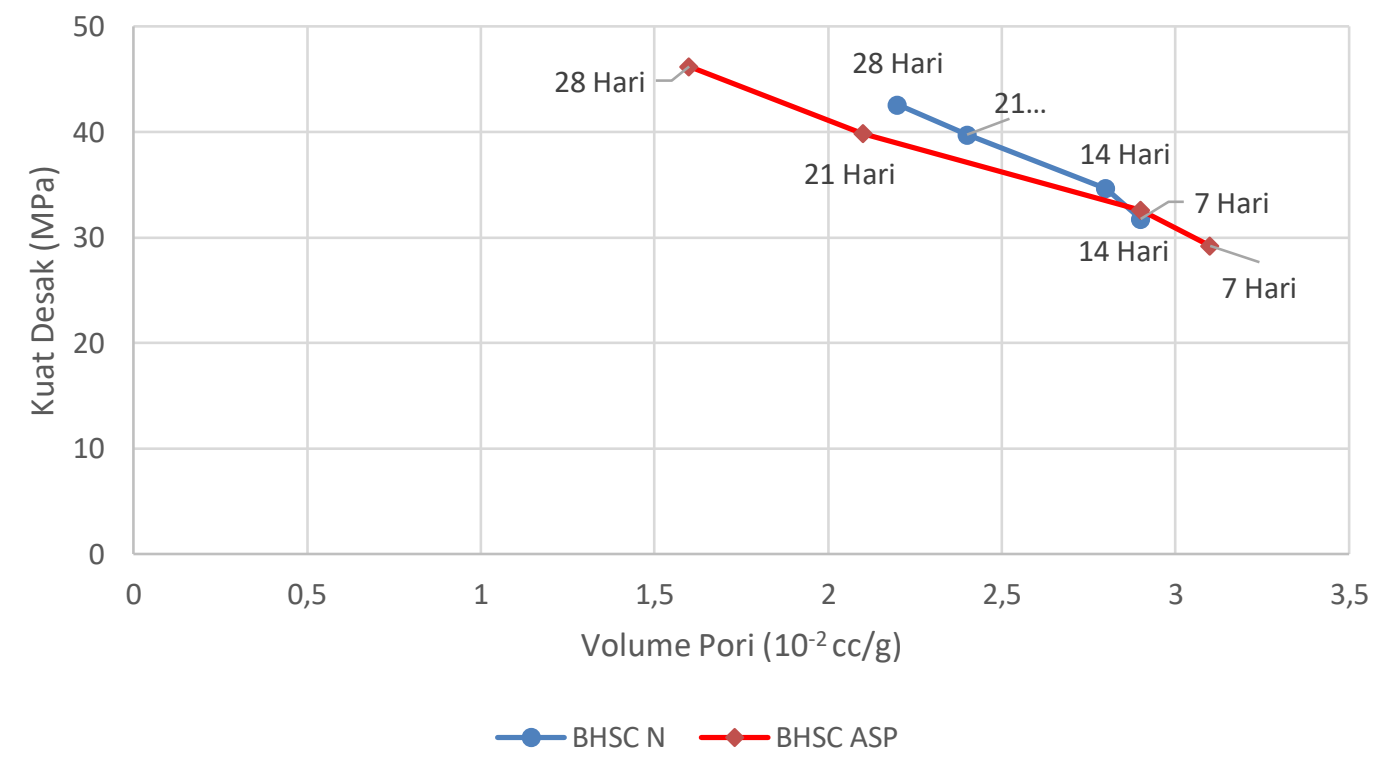


Gambar 5. Hubungan Volume Pori terhadap Kuat Desak Beton

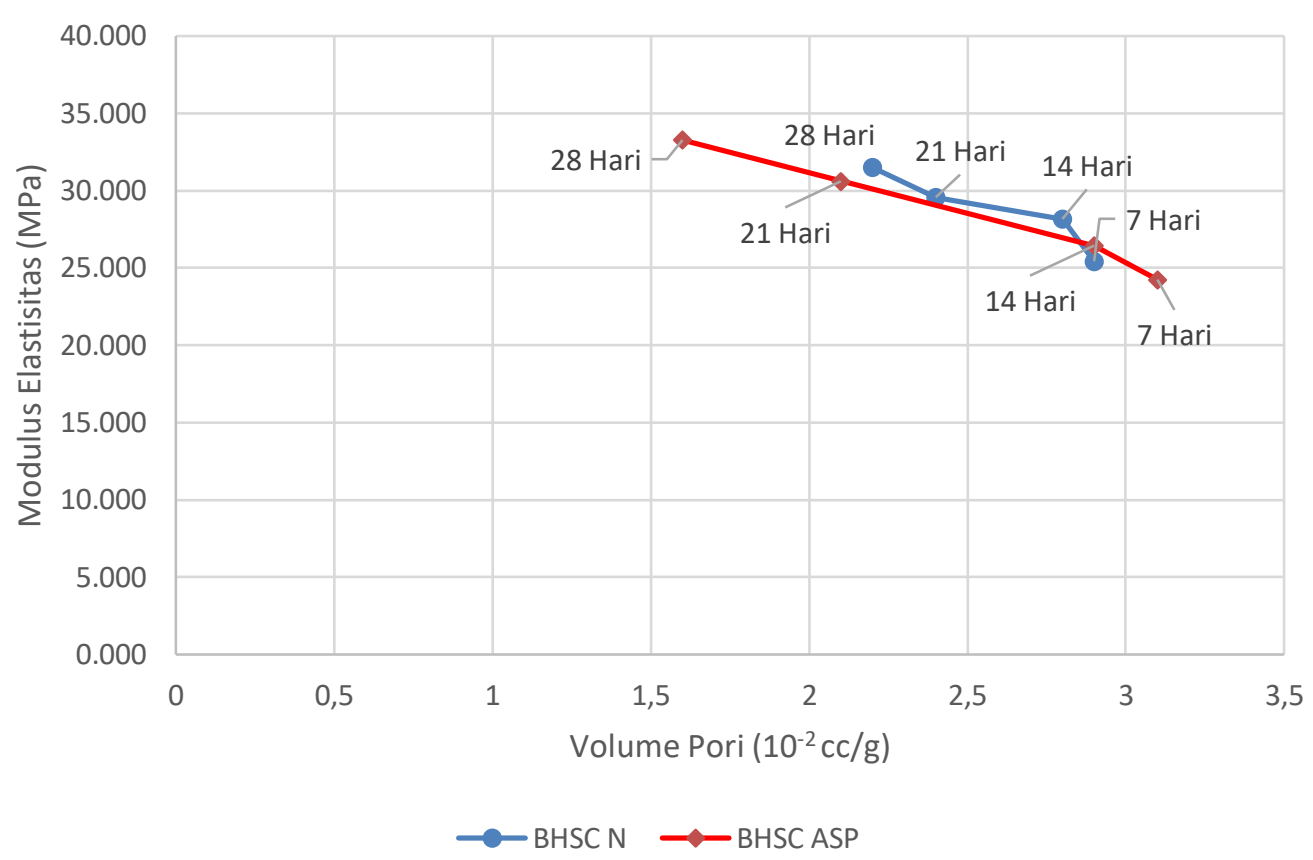

Gambar 6. Hubungan Volume Pori terhadap Modulus Elastisitas Beton

\section{SIMPULAN}

1. Peningkatan nilai kuat desak Beton $B_{H S C}$ ASP terhadap $B_{H S C} N$ pada umur ke- 7, 14, 21, dan 28 hari masingmasing sebesar $-8,04 \% ;-5,96 \% ; 0,34 \% ; 8,45 \%$. Hasil tersebut sesuai dengan yang didapat dari hasil uji SAA (Surface Area Analysis) dimana peningkatan nilai volume pori pada beton $\mathrm{B}_{\mathrm{HSC}}$ ASP terhadap $\mathrm{B}_{\mathrm{HSC}} \mathrm{N}$ pada umur ke- 7, 14, 21, dan 28 hari masing-masing sebesar 6,90\%; 3,57\%; -12,50\%; -27,27\%.

2. Peningkatan nilai modulus elastisitas Beton $B_{\mathrm{HSC}}$ ASP terhadap $\mathrm{B}_{\mathrm{HSC}} \mathrm{N}$ pada umur ke- 7, 14, 21, dan 28 hari masing-masing sebesar $-3,01 \% ;-2,23 \% ; 0,13 \% ; 3,14 \%$. Hasil tersebut sesuai dengan yang didapat dari hasil uji SAA (Surface Area Analysis) dimana peningkatan nilai volume pori pada beton $\mathrm{B}_{\mathrm{HSC}}$ ASP terhadap $\mathrm{B}_{\mathrm{HSC}} \mathrm{N}$ pada umur ke- 7, 14, 21, dan 28 hari masing-masing sebesar 6,90\%; 3,57\%;-12,50\%;-27,27\%.

\section{UCAPAN TERIMA KASIH}

Terima kasih penulis ucapkan kepada Laboratorium Bahan Fakultas Teknik Universitas Sebelas Maret yang telah menyediakan sarana dan prasarana yang menunjang untuk penelitian ini.

\section{REFERENSI}

Anonim. American Society for Testing and Material. 1991. ASTM C 618 Standard Test Methode for Fly Ash and Row of calcined Natural Pozzolan for Use as a Mineral Admixture in Portland Cement Concrete. USA.

Anonim. Badan Standardisasi Nasional. 2000. Tata Cara Perencanaan Beton Kekuatan dengan Semen Portland dan Abu Terbang. SNI 03-6468-2000. Badan Standarisasi Nasional, Jakarta.

Hardjasaputra, H. 2008. Teknologi Beton. Andi, Yogyakarta, Indonesia.

Mulyono, T. 2003. Teknologi Beton. Penerbit Andi Offset, Yogyakarta.

Mulyono, T. 2005. Teknologi Beton. Penerbit Andi Offset, Yogyakarta.

Robbani. 2018. Pengaruh Kadar Rice Husk Ash Terhadap Kuat Tekan pada High Strength Self Compacting Concrete (HSCC). Jurnal Program Studi Teknik Sipil, Fakultas Teknik, Universitas Sebelas Maret Surakarta, Indonesia.

Tjokrodimuljo, K. 1992. Teknologi Beton. Arif: Yogyakarta.

Zhang, M. H., Lastra, R., and Malhotra, V.M. 1996. Rice Husk Ash Paste and Concrete: Some Aspects of Hydration and the Microstructure of The Interfacial Zone Between The Aggregate and Paste. Cement and Concrete Research, Vol. 26, No. 6, hal 963-977. 